\title{
Gerhard Wegner
}

\section{Ökonomischer Liberalismus als politische Theorie}

\author{
Befund, Kritik, Rekonstruktion
}

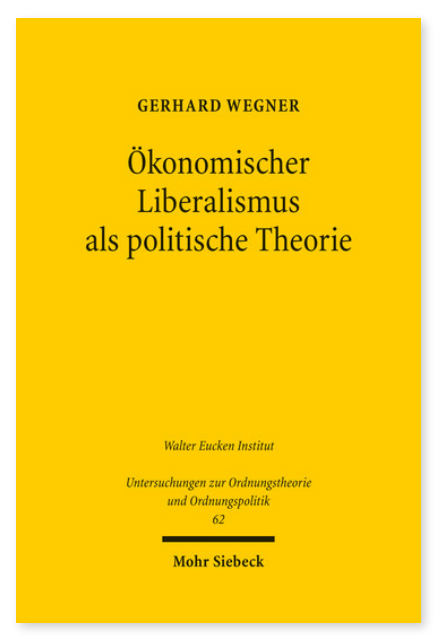

2012. XII, 292 Seiten. UOrd 62

ISBN 978-3-16-151874-4

DOI 10.1628/978-3-16-151874-4

eBook PDF 74,00€

ISBN 978-3-16-151034-2

fadengeheftete Broschur 74,00€
Während der klassische ökonomische Liberalismus die Wohlstandsinteressen der Bürger gegenüber einem nicht demokratisch legitimierten Herrscher vertrat, wenden sich die modernen Varianten des Liberalismus an den Bürger als Souverän der Gesetzgebung. Das klassische Modell verliert unter dieser grundlegenden politischen Veränderung jedoch seinen ursprünglichen Geltungsanspruch. Gefordert ist nunmehr die demokratietheoretische Verortung einer wirtschaftspolitischen Konzeption, die in der demokratischen Öffentlichkeit Europas nur eine Mindermeinung darstellt. Zu diesem Zweck rekonstruiert Gerhard Wegner den ökonomischen Liberalismus aus der Perspektive des politischen Liberalismus. Er interpretiert Hayeks Theorie der spontanen Ordnung neu: sie tritt als legitime Ideologiekritik legitimer politischer Präferenzen auf. Metaphorisch gesprochen bildet der moderne ökonomische Liberalismus den Dialogpartner einer mit sich unzufrieden gewordenen demokratischen Öffentlichkeit, die ihre Wohlstandserwartungen enttäuscht sieht.

Gerhard Wegner ist Inhaber des Lehrstuhls für Institutionenökonomie und Wirtschaftspolitik an der Staatswissenschaftlichen Fakultät, Universität Erfurt.

Jetzt bestellen:

https://mohrsiebeck.com/buch/oekonomischer-liberalismus-als-politische-theorie-9783161518744?no_cache=1 order@mohrsiebeck.com

Telefon: +49 (0)7071-923-17

Telefax: $+49(0) 7071-51104$ 